\title{
Resistance of modified wood to marine borers
}

\author{
Andre Klüppel ${ }^{a^{*}}$, Simon M. Cragg ${ }^{\mathrm{b}}$, Holger Militza ${ }^{\mathrm{a}}$, Carsten Mai ${ }^{\mathrm{a}}$ \\ a Wood Biology and Wood Products, Burckhardt Institute, Georg-August-University G€ottingen, Büsgenweg 4, 37077 G€ottingen, Germany \\ b Institute of Marine Sciences, School of Biological Sciences, University of Portsmouth, Ferry Road, Portsmouth PO4 9LY, UK \\ ${ }^{*}$ Corresponding author. \\ E-mail addresses: akluepp@gwdg.de (A. Klüppel),simon.cragg@port.ac.uk \\ (S.M. Cragg), hmilitz@gwdg.de (H. Militz), cmai@gwdg.de (C. Mai).
}

\section{Abstract}

The resistance of differently modified wood to the common shipworm, Teredo navalis, and the wood boring crustacean, Limnoria quadripunctata, was assessed in a field trial and by means of a short term laboratory assay, respectively. Scots pine (Pinus sylvestris) sapwood was treated with TEOS (tetra-ethoxyorthosilane) and different thermosetting resins, namely phenol formaldehyde (PF) and methylated melamine formaldehyde (MMF). Additionally, acetylated and untreated radiata pine (Pinus radiata) was included. In the field trial according to EN 275 in the Baltic Sea over a period of six years the specimens were exclusively attacked by $T$. navalis. For the laboratory assay, matchstick-sized samples cut from spare panels prepared for the field trial were subjected to individuals of L. quadripunctata; faecal pellet production served as a measure of feeding rate. Treatments that prevented shipworm attack in the field also reduced feeding of L. quadripunctata in the laboratory assay: efficacy of resin treatments was enhanced by parameters that increase the amount of resin in the cell wall (i.e. high WPG and dry curing conditions); acetylation resulted in high resistance; and TEOS treatment was not effective. The results suggest that modification on cell wall level is required to impart marine borer resistance.

\section{Introduction}

Wood has a number of advantages that make it a competitive material for waterfront structures such as groynes, jetties, and dolphins (Crossman and Simm, 2004). The service life of such structures, however, is often limited due to degradation of the below water portions (use class 5; EN 335, 2007) by marine borers. In temperate waters, two types of borers cause significant damage: teredinids (shipworms) and limnoriids (gribbles) (Oliver, 1974). Attack by these organisms is traditionally prevented by treating wood with biocidal wood preservatives or by using tropical timber species that are naturally resistant. The use of biocidal wood preservatives, however, has been legally restricted during implementation of the Biocidal Products Directive (1998) and resistant timbers with a proven track record are poorly available in large dimensions required for many applications. Moreover, there are environmental concerns regarding the utilization of such timbers as it might contribute to tropical deforestation (Williams et al., 2004). Plastic barriers can effectively protect wood piles from shipworms, but installation is costly and barriers are often susceptible to mechanical damage that exposes unprotected wood (Morrell et al., 1984). Wood modification might be an alternative to protect European species or plantation grown timbers in marine environments, because, by definition, modified wood is non-toxic and does not release toxic substances during service or disposal (Hill, 2011). Wood modification involves various methods to improve dimensional stability, durability, weathering resistance, etc. Most modification processes are based on the application of heat (thermal modification), chemical reaction of cell wall polymers with a reactant (chemical modification) or deposition of the modification agent within the wood substance (impregnation modification). Impregnation modification with an agent that does not penetrate the cell wall is referred to as lumen treatment. Early studies on chemically modified wood suggested that acetylation increases resistance to marine borers (Tarkow et al., 1955; Johnson and Rowell, 1988); but in another test acetylated wood failed after only two years due to attack by both teredinids and limnoriids (Larsson Brelid et al., 2000). In the most extensive marine trial on differently modified wood to date limnoriids were hardly active so that only shipworm resistance was tested (Westin et al. 2006). This trial confirmed improved resistance of acetylated wood (Larsson Brelid andWestin, 2010), with weight percent gains (WPG: percentage increase in dry mass due to modification) being ca. $20 \%$ in all studies mentioned. In the same study, chemical modification by maleoylation and succinylation did not increase shipworm resistance, while impregnation modification with furfuryl alcohol and methylated melamine formaldehyde (MMF) prevented attack at WPGs higher than $20 \%$. Thermal modification and lumen treatment with oil did not impart resistance.

In all the studies mentioned above, marine borer resistance has been assessed using a marine field trial. These trials usually need to extend over several years to generate meaningful findings; according to EN 275 (1992) results should be interpreted only after a minimum period of five years. Furthermore, a test site with an active population of both teredinids and limnoriids is required to reliably predict durability in European marine waters. Due to the life cycle and dispersal strategy of limnoriids, attack by this group of borers is not guaranteed at 
many sites. Therefore, Borges et al. (2009) developed a short term laboratory assay for measuring feeding of Limnoria under forced feeding conditions. Using this assay, modification with DMDHEU (dimethyloldihydroxyethylene- urea) (Borges et al., 2004) and acetylation (Papadopoulos et al., 2008) were shown to reduce the feeding rate of Limnoria quadripunctata.

This study investigates the resistance of differently modified wood to marine borers. It focuses on impregnation modification with thermosetting resins, but it also includes acetylated wood and silica containing wood. Shipworm resistance is assessed in a marine field trial in the Baltic Sea with a duration of six years. No limnoriids were active at the test site. Therefore, resistance to limnoriids was tested using the laboratory assay developed by Borges et al. (2009).

\section{Materials and methods}

\subsection{Wood treatment}

Except for acetylation, all treatments investigated in this study (Table 1) were applied to Scots pine (Pinus sylvestris L.) sapwood. Wood was modified with two thermosetting resins: methylated melamine formaldehyde (MMF, Madurit® MW 840/75WA; INEOS Melamines, Frankfurt am Main, Germany), and phenol formaldehyde (PF, Phenodur® PR 635/78WA, Allnex Germany GmbH, Wiesbaden, Germany, Mn 1/4 ca. 400 g mol_1). Modification with MMF $10 \%$ was carried out on a pilot plant (Krause, 2008; process 5). For lab scale modification with MMF $25 \%$ and PF $25 \%$ the impregnated specimens were cured and dried in an oven. MMF $25 \%$ treated specimens were dried and cured simultaneously (dry curing; Klüppel and Mai, 2013). PF 25\% treated specimens were wrapped in polyethylene terephtalate (PET) for curing and subsequently dried (wet curing) because dry curing led to severe cracking. Tetra-ethoxy-ortho-silane (TEOS, Dynasilan A®, Evonik Industries AG, Rheinfelden, Germany) was applied in sol state as described by Donath et al. (2004). Titan Wood B.V. (Arnhem, Netherlands) supplied Accoya ${ }^{\circledR}$, which is Radiata pine (Pinus radiata D. Don) chemically modified with acetic anhydride. Reference specimens were treated with acid copper chromate composed of $30 \%(\mathrm{~m} / \mathrm{m}) \mathrm{CuO}$ and $70 \%(\mathrm{~m} / \mathrm{m}) \mathrm{CrO}$. Concentrations of the preservative solution were chosen to result in retentions of copper and chromium comparable to the reference treatments suggested in the European standard EN 275 (1992). The preservative treated specimens were stored at room temperature for 8 weeks to ensure fixation of the chemical. Specimens for the laboratory assay were cut from spare panels prepared for the field test, except for the PF-modified wood. While PF-modified panels for the field test were cured wet, specimens for the laboratory assay were cut from dry cured panels (Klüppel and Mai, 2013). Although dry curing led to severe cracking, sound specimens needed for laboratory could be produced from these panels.

\subsection{Field trial}

\subsubsection{Installation and evaluation}

When wood was modified on lab scale, panels measuring $200 \times 75$ x $25 \mathrm{~mm} 3(1 \times \mathrm{r} \times \mathrm{t})$ were treated. Accoya ${ }^{\circledR}$ and MMF (10\%) treated specimens were cut from boards after treatment. Ten specimens of each treatment were prepared with a hole of $16 \mathrm{~mm}$ in diameter in the middle and attached to ladder-like racks made of construction steel similar to the arrangement described in Annex A of EN 275 (1992). Plastic tubes of 25 mm length served as spacers between the specimens.

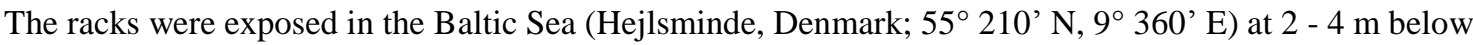
medium high tide. Salinity at the test site ranges between 15 PSU and 25 PSU (practical salinity unit; corresponds to $1.5 \ldots 2.5 \%$ ). Water temperature varies between $0-5{ }^{\circ} \mathrm{C}$ in January and $20-25{ }^{\circ} \mathrm{C}$ in August with four to five months per year above the common shipworm's spawning temperature of $14{ }^{\circ} \mathrm{C}$ (Nair and Saaraswathy, 1971; NERI, 2009). The exposure started in May 2008; PF-treated specimens were included in 2010. Samples were examined annually in winter or spring. At each inspection, the fouling on differently treated samples was compared visually. Then the fouling organisms were carefully removed with a scraper and the specimens were X-rayed and reinstalled in the water. Each specimen was rated according to the European standard EN 275 (Table 2). For each treatment, the ratings of all test specimens were added up and divided by the respective number of replicates to obtain a notional average rating.

Five new untreated controls of Scots pine sapwood were exposed each year. Pallets extracted from rejected controls were used to identify the shipworm species. 


\subsubsection{Chemical retention}

The content of modification chemicals or preservatives in the panels was determined after one, two and three years. Initial contents (of non-exposed specimens) were determined using spare specimens treated in the same batch as the specimens used in the trial. For sampling, a hole, $10 \mathrm{~mm}$ in diameter, was drilled into a corner of each panel and about $1 \mathrm{~g}$ of the wood powder was collected. The acetyl content of the acetylated wood was calculated from the amount of acetic acid determined by HPLC (Breeze System, Waters Corporation, Milford, USA with Aminex HPX-87H column, Bio-Rad Laboratories Inc., Hercules, USA) after saponification with $0.5 \mathrm{M} \mathrm{NaOH}$. For MMF-treatment, the N/C-ratio served as an indicator of the chemical content. The CHN analyzer Vario EL III (Elementar Analysensysteme GmbH, Hanau, Germany) was used to determine the samples' content of nitrogen and carbon. The chemical retention of silicate in wood formed from TEOS was assessed as acid insoluble ash referring to DIN 54373 (1989). The references' copper content was determined by ICP-OES (Inductively Coupled Plasma e Optical Emission Spectroscopy, Ciros CCD,

SPECTRO Analytical Instruments GmbH, Kleve, Germany) after decomposition by acid hydrolysis under pressure. Chemical retention in PF-treated specimens was not determined.

The chemical content of each exposed specimen was normalised to the median of the non-exposed controls of the respective treatment to assess chemical retention during exposure.

\subsection{Laboratory assay}

\subsubsection{Feeding test}

Wood sticks measuring 20 (1) $\times 2.5 \times 4 \mathrm{~mm}^{3}$ from the middle part of the original panels were vacuum impregnated with sea water and leached for 14 days. For the test, a single stick was placed in a well of a 12-well cell culture tray along with $5 \mathrm{~mL}$ seawater and an individual of L. quadripunctata. A culture tray was prepared for each treatment as well as for untreated controls of Scots pine and Radiata pine (n $1 / 412)$. Faecal pellets produced by the gribbles feeding on the sticks were counted twice a week at 3-day and 4-day intervals over a period of three weeks. For counting, the animals and their corresponding stick were transferred to a second set of cell culture trays prefilled with seawater; dead animals were replaced. Each well of the used tray, containing only water and faecal pellets, was then photographed with a camera equipped microscope and an automated pellet counting procedure was employed, which is based on the public domain image processing software ImageJ (Abramoff et al., 2004; Malyon, 2011). Data from counting intervals during which the animal died or moulted were excluded from the analysis. Mortality was calculated as percentage number of counting intervals in which an animal died. Half of the water was changed in the middle of the 4-day interval to avoid accumulation of substances leached from the sticks. Faecal pellet production rates varied over time but did not show a clear trend. Therefore, the mean value was calculated for each well.

\subsubsection{Choice test}

A choice test was set up to evaluate the influence of leached copper on the pellet production rate of animals feeding on preservative treated wood. Sticks treated with $0.6 \%$ acid copper chromate and untreated controls of Scots pine were cut into half. Five cell culture trays with an identical setup were prepared: Each tray included four wells with treated specimens, untreated specimens and both treated and untreated specimens. Pellets were counted after three and seven days. After the 3-day interval, one $\mathrm{mL}$ of water from each well was collected in a single container and the copper concentration of the mixture was determined by ICP-OES (Inductively Coupled Plasma e Optical Emission Spectroscopy, Ciros CCD, SPECTRO Analytical Instruments GmbH, Kleve, Germany).

\subsection{Statistics}

Where the median was chosen as a measure of central tendency, $95 \%$ confidence intervals (CI) were calculated as follows:

$\mathrm{CI}=1.7 \times 1.25 R$

$$
1.35 \sqrt{\mathrm{N}}
$$

where $\mathrm{R}$ is the interquartile range; and $\mathrm{N}$ is the number of observations. If the confidence intervals of "two medians do not overlap the medians are, roughly, significantly different at about a $95 \%$ confidence level." (McGill et al., 1978). 
Mortality in the feeding test represents a binomial proportion (probability of an animal being dead at the end of a counting interval), so that the confidence interval was calculated according to Clopper and Pearson (Clopper and Pearson, 1934).

\section{Results}

\subsection{Field trial}

Fouling communities on differently treated panels were visually similar and, thus, seemed to be unaffected by the treatments. The only wood boring species being active at the test site was the common shipworm, Teredo navalis. Shipworm attack on untreated controls was extensive: with the exception of the season 2012, untreated controls were rated at least three (severely attacked) after the first year (rating system see Table 2); and they were always destroyed within two years of exposure (average life: 1.3 years). Infestation of low concentration reference specimens started in the third year (Fig. 1) and progressed very fast so that all specimens were destroyed after six years, with an average life of 4.8 years. Only one of the ten references impregnated with $2.5 \%$ acid copper chromate was attacked by a single individual after six years.

Untreated Radiata pine was even more susceptible to shipworm attack than Scots pine; Accoya ${ }^{\circledR}$ specimens (acetylated Radiata pine), however, remained sound. The same was true for wood treated with MMF $25 \%$. Resin impregnated wood cured under non-drying conditions, i.e. MMF 10\% and PF 25\%, showed poor resistance (Fig. 1). Specimens modified with TEOS were considerably attacked in the first two seasons, but infestation progressed slower than in untreated controls or MMF $10 \%$ treated wood. Also, the pattern of attack in specimens treated with TEOS differed considerably from that in specimens treated with MMF $10 \%$ and PF $25 \%$ : the first were infested by a high number of small individuals, while the latter exhibited few but larger animals, i.e. burrows (Fig. 2).

Median chemical contents of specimens after three years of exposure ranged between $80 \%$ and $120 \%$ of those of non-exposed panels (Fig. 3). Variations do not show a clearly decreasing trend and, thus, seem to result from spatial variations of chemical content within single specimens rather than from leaching. The median copper content of preservative treated specimens, however, decreased by ca. $1 \mathrm{~g}(\mathrm{Cu})$ per $\mathrm{kg}$ (wood) for both concentrations of preservative solution. For the low concentration reference specimens, this corresponds to a significant proportional loss of ca. 50\% after three years, while e due to large variation e for the high concentration specimens leaching of copper is not statistically significant (Fig. 3).

\subsection{Laboratory assay}

The highest pellet production rate was from animals feeding on untreated controls; the lowest from those feeding on sticks treated with acid copper chromate (Fig. 4). The modification methods can be divided into three groups with high, medium, and low pellet production. Two out of three modifications that did not prevent shipworm attack in the field test, resulted in high pellet production rate: treatment with MMF 10\% and TEOS. The phenolic resin also conferred low shipworm resistance in the field test when cured wet, but resulted in a medium pellet production rate in the laboratory test when cured dry. Acetylation performed best.

Wood treated with $0.6 \%$ acid copper chromate caused distinctly higher mortality than any other material (Fig. 5). Pellet production rate in the choice test was near to that of animals fed solely preservative treated wood (Fig. 6) with a maximum of 14 pellets per day. Mortality in the choice test was between that of animals fed the untreated and preservative treated controls.

\section{Discussion}

\subsection{Test site}

The severity of a test site increases with the quantity of borers present at the site and water temperature. Therefore, the average life of specimens and controls depends on the test area (Sen et al.

2009). Activity of both teredinids and limnoriids is desirable, to evaluate the resistance to both types of borers in a single test. However, diversity of borers does not seem to necessarily affect field test results, as there is no evidence in literature that any species prefers a particular timber or material (e.g. Sivrikaya et al., 2009). In the present study, the average life of untreated Scots pine controls was 1.3 years, while controls were usually destroyed within one year in other published field tests. Average life of low retention reference specimens was 4.6 years compared to 3.2 years at a site near Kristineberg, Sweden (Westin et al. 2006). At Koper, Slovenia, preservative treated reference specimens were completely sound after 32 months (Humar and Lesar, 2013). Comparing results from different sites is difficult, because severity of attack also varies over time. Overall, 
attack by marine borers at the present field seems to be slightly less severe than at fields used in most other studies; especially those in warmer areas. This needs to be taken into account, when the average life of test specimens is compared with results of other tests.

\subsection{Modification}

The findings described above show that wood modification with a thermosetting resin can improve resistance to both teredinids and limnoriids. Resin treatments seem to protect wood against shipworms by inhibiting the settlement of larvae; but once established individuals may grow at a similar rate as those in untreated controls. Modifications that prevented infestation by shipworms in the field trial were also particularly effective in reducing feeding rates of $L$. quadripunctata in the laboratory assay. Efficacy of a treatment seemed to depend mainly on WPG (percentage increase in dry mass due to modification) and process conditions, rather than type of resin. This suggests that the crucial factor for a resin treatment to protect wood against marine borers is the amount of resin deposited in the cell wall. Provided that the resin molecules are sufficiently small to access the cell wall micropores, the total amount of resin entering the cellwall is determined by WPG and degree of cell wall penetration, i.e. proportion of resin in the cell wall rather than in the lumen. Severe (i.e. dry) curing conditions enhance degree of cell wall penetration (Klüppel and Mai, 2013) and, thus, may increase efficacy against borers. Additionally, curing under dry conditions results in the accumulation of resin in the panels' surface layers; and, thus, increases the local WPG at the point of larval attack in field test panels (Klüppel and Mai, 2013). The importance of curing conditions becomes particularly clear with regard to PFtreated wood: while, generally, the relative effects of the different treatments were similar in the field trial and laboratory assay, PF-treated panels exhibited poor resistance in the field (wet cured) but performed distinctly better in the laboratory test (dry cured). Resin deposited in the cell wall reduces pore size by occupying void space (Dieste et al., 2009) and increases cell wall stiffness and hardness (Gindl and Gupta, 2002), because the resin formed in the micropores is more brittle than the original cell wall; majorchemical changes of the cell wall polymers (covalent bonding) are unlikely at least for PF (He and Riedel, 2004) and MMF (Lukowsky, 1999) treatments. Pore size reduction might render the cell wall less accessible for enzymes and, thus, micropore blocking has been suggested as a possible mechanism for the decay resistance of modified wood. The same may apply to marine borer resistance.

Another possible mechanism of resin treatments to improve resistance to marine borers may be hampering the mechanical breakdown of the wood. To do so, it seems crucial that hardness is improved on the cell wall level, because enhancing macroscopic hardness by lumen filling does not impart resistance to marine borers.

Acetylation does not increase cell wall hardness (Moon et al., 2007), which demonstrates that hardness cannot be sole protection mechanism of modified wood. Instead, the protective effect of acetylation may be either micropore blocking or enzyme nonrecognition of the chemically altered wood polymers. Lumen treatment with TEOS did not seem to protect the wood against infestation by shipworm larvae but to slow down growth of the animals within the wood or to restrict their maximum size. Impregnation with the pre-hydrolysed (i.e. oligomeric) silane mainly results in the deposition of silica granules in the cell lumens (Donath et al., 2004). High silica content has long been regarded as a factor contributing to the natural resistance of some tropical timber species (Eaton and Hale, 1993), but the mode of action is still not understood. Some authors suggest different mechanical effects: blunting of the shipworms' rasping shells and gribbles mandibles, respectively, inhibition of the digestive system through accumulation of waste debris (Cookson et al., 2007), or disruption of the gut by sharp-edged aggregates (Scown et al., 2001). Accordingly, the effectiveness of silica probably depends on the granules' distribution, size, shape, and hardness, with the latter being determined by the silica's molecular structure. Scown et al. (2001) impregnated wood with tetra-ethoxy-ortho-silane (TEOS), which leads to the precipitation of silica mainly in the lumens, and found that resistance to marine borers depends on the precipitation method. Precipitation by heat curing e similar to the method used in this study e improved resistance to both types of borers, but the treatment was more effective against teredinids than against limnoriids. The impregnation solution in this study, however, contained more water available for pre-hydrolysis and was not diluted with methanol. This may have led to the formation of larger, less dispersed granules that could be avoided by the shipworms in the early stages of development and by limnoriids in general.

\subsection{Acid copper chromate}

During the field trial, acid copper chromate leached from the wood, with proportional loss of copper being significant only for the specimens treated to a lower initial concentration. In the literature, findings on the correlation between initial preservative retention and rate of leaching differ considerably; e.g. Archer et al. 
(1994) observed a similar pattern as found in this study for loss of arsenic from CCA treated wood and assumed that it results from the higher amount of chromium in the system. An ultimate explanation on how leaching resistance of acid copper chromate depends on its concentration does not exist.

Leached copper did not seem to affect the growth of fouling organisms on the specimens' surface, but specimens treated with CC $0.6 \%$ were heavily attacked by shipworms in the fourth and fifth year after staying sound for three years. A similar progression, with delayed infestation that advances rapidly once started, was also found for wood treated with a leachable copper-organic wood preservative (not shown) and seems to be indicative for preservative depletion.

In the feeding test, pellet production rate of L. quadripunctata fed CC $0.6 \%$ treated wood was very low, while mortality was high. This indicates a toxic effect, which may occur due to ingestion of copper or via uptake of leached copper by the respiratory limbs. Low pellet production in the choice test suggests that pellet production rate was influence by leached copper. If copper dissolved in the water had no effect, feeding of those individuals that chose the untreated sticks would not have been reduced. Therefore, we conclude that even if acute toxicity may require ingestion of the preservative treated wood, leached copper sufficiently harmed the animals to stop them feeding.

In contrast to a static seawater test in small containers, leached substances are rapidly diluted in a marine environment. Consequently, this test does not allow drawing conclusions on the resistance of preservativetreated wood under service conditions. Different performance of the low concentration reference specimens in the field trial and laboratory assay is not due to the different types of borers but result from a more rapid dilution of leached copper in the field. Borges et al. (2008) suggested a laboratory assay with running seawater for tropical hardwoods containing water-soluble extractives. Such a set-up is also required to reliably predict service performance of preservative treated wood. The modification chemicals included in this study were shown to be stable in sea water, so that the respective test results should be unaffected by leaching.

\section{Conclusions}

Impregnation modification with thermosetting resins and chemical modification by acetylation can confer resistance to marine borers to non-durable timber species. Treatments that prevented shipworm attack in the field also reduced feeding of L. quadripunctata in the laboratory assay. Therefore, it is concluded that the same protection mechanisms are attributable to the resistance against both teredinids and limnoriids. Efficacy of resin treatments was enhanced by high loadings and dry curing conditions. The mode of action marine borer resistance remains unclear. Protection mechanisms may be based on increased cell wall hardness, blocking of cell wall micropores or enzyme non-recognition of chemically altered wood polymers.

\section{Acknowledgements}

We acknowledge the financial support of this work by the "Fachagentur Nachwachsende Rohstoffe (FNR)" (Agency for Renewable Resources) (Project No. 22004407) and the organisational support in the field trial by Angela Steinfurth and Johann Müller. We would like thank Graham Malyon for guidance during the feeding assay.

\section{References}

Abramoff, M.D., Magelhaes, P.J., Ram, S.J., 2004. Image processing with Image J. Biophot. Int. 11 (7), $36-42$. Archer, K., Preston, A., Chittenden, C., Page, D., 1994. Depletion of Wood Preservatives after Four Years' Marine Exposure in Mt. Maunganui Harbour, NZ. IRG/WP/94e50036. The International Research Group on Wood Preservation, Stockholm.

Biocidal Products Directive, 1998. Directive 98/8/EC of the European Parliament and of the Council of 16 February 1998 Concerning the Placing of Biocidal Products on the Market, $63 \mathrm{pp}$.

Borges, L.M.S., Cragg, S., Bergot, J., Williams, J.R., Shayler, B., Sawyer, G.S., 2008. Laboratory screening of tropical hardwoods for natural resistance to the marine borer Limnoria quadripunctata: the role of leachable and nonleachable factors. Holzforschung 62 (1), 99-111.

Borges, L.M.S., Cragg, S.M., Busch, S., 2009. A laboratory assay for measuring feeding and mortality of the marine wood borer Limnoria under forced feeding conditions: a basis for a standard test method. Int. Biodeterior. Biodegr. 63 (3), 289-296.

Borges, L.M.S., Cragg, S.M., van der Zee, M., 2004. Evaluating the potential of modified wood for use in marine environments using a short-term laboratory Bioassay. IRG/WP 04-10525. The International Research Group on Wood Preservation, Stockholm. 
Clopper, C.J., Pearson, E.S., 1934. The use of confidence or fiducial limits illustrated in the case of the binomial. Biometrika 26, 404-413.

Cookson, L.J., Scown, D.K., McCarthy, K.J., 2007. The effectiveness of silica treatments against wood-boring invertebrates. Holzforschung 61, 326-332.

Crossman, M., Simm, J., 2004. Manual on the Use of Timber in Coastal and River Engineering. Thomas Telford Publishing, London.

DIN 54373, 1989. Testing of Pulp, Paper and Board; Determination of Acid Insoluble Proportion of Ignition Residue.

Dieste, A., Krause, A., Mai, C., Sebe, G., Grelier, S., Militz, H., 2009. Modification of Fagus sylvatica L. with 1,3dimethylol-4,5-dihydroxy ethylene urea (DMDHEU). Part 2: pore size distribution determined by differential scanning calorimetry. Holzforschung 63 (1), 89-93.

Donath, S., Militz, H., Mai, C., 2004. Wood modification with alkoxysilanes. Wood Sci. Technol. 38, 555-566.

Eaton, R.A., Hale, M.D.C., 1993. Wood: decay, pests and protection. Chapman \& Hall, London.

EN 275, 1992. Wood preservatives e Determination of the Protective Effectiveness against Marine Borers.

EN 335-1, 2007. Durability of Wood and Wood-based Products. Definition of Use Classes. Part 1: General.

Gindl, W., Gupta, H.S., 2002. Cell-wall hardness and Young's modulus of melamine modified spruce wood by nanoindentation. Compos Pt A-Appl Sci. Manuf. 33(8), 1141-1145.

He, G., Riedel, B., 2004. Curing kinetics of phenol formaldehyde resin and wood-resin interactions in the presence of wood substrates. Wood Sci. Technol. 38(1), 69-81.

Hill, C.A.S., 2011. Wood Modification: an update. BioResources 6 (2), 918-919.

Humar, M., Lesar, B., 2013. Performance of native and copper-ethanolamine-treated wood exposed to seawater at port of Koper, Slovenia. Drv. Ind. 64 (4), 273-279.

Johnson, B.R., Rowell, R.M., 1988. Resistance of chemically modified wood to marine borers. Mater. Org. 23 (2), $147-$ 156.

Klüppel, A., Mai, C., 2013. The influence of curing conditions on the chemical distribution in wood modified with thermosetting resins. Wood Sci. Technol. 47 (3), 643-658.

Krause, A., 2008. Endbericht zum DBU-Projekt: Einsatz von modifiziertem Holz zur Verbesserung der Eigenschaften von Holzfenstern. Abteilung Holzbiologie und Holzprodukte. Universität Göttingen.

Larsson Brelid, P., Simonson, R., Bergmann, O., Nilsson, T., 2000. Resistance of acetylated wood to biological degradation. Holz als Roh- Werkst. 58 (5), 331-337.

Larsson Brelid, P.,Westin, M., 2010. Biological Degradation of Acetylated Wood after 18 Years in Ground Contact and 10 Years in Marine Water. IRG/WP 10-40522. The International Research Group on Wood Preservation, Stockholm.

Lukowsky, D., 1999. Holzschutz mit Melaminharzen. PhD thesis. University of Hamburg, Hamburg, Germany.

Malyon, G., 2011. Insight into the Digestive Processes of the Wood-boring Marine Crustacean Limnoria quadripunctata. PhD thesis. University of Portsmouth, Portsmouth, UK.

McGill, R., Tukey, J.W., Larsen,W.A., 1978. Variations of box plots. Am. Statistician 32 (1), 12-16.

Moon, R.J., Jakes, J.E., Beecher, J.F., Frihart, C.R., Stone, D.S., 2007. Relating nano indentation to macro indentation of wood. In: Hse, C., Jiang, Z., Kuo, M.L. (Eds.), Advanced Biomass Science and Technology for Bio-based Products: Proceedings, Beijing, China, pp. 145-160.

Morrell, J.J., Helsing, G.G., Graham, R.D., 1984. Marine wood Maintenance Manual: a Guide for Proper Use of Douglas-fir in Marine Exposures. Oregon State University, Forest Research Lab, Corvallis.

Nair, N.B., Saraswathy, M., 1971. The biology of wood boring teredinid molluscs. Adv. Mar. Biol. 9, 335-509.

NERI., 2009. MADS Online Database. National Environmental Research Institute.

Oliver, A.C., 1974. Timber for Marine and Freshwater Construction. Timber Research and Development Association, High Wycombe, UK.

Papadopoulos, A.N., Duquesnoy, P., Cragg, S.M., Pitman, A.J., 2008. The resistance of wood modified with linear chain carboxylic acid anhydrides to attack by the marine wood borer Limnoria quadripunctata Holthius. Int. Biodeterior. Biodegrad. 61, 199-202.

Scown, D.K., Cookson, L.J., McCarthy, K.J., 2001. Silica Treatments to Protect Timber from Marine Borers. IRG/WP 01-30270. The International Research Group on Wood Preservation, Stockholm.

Sen, S., Sivrikaya, H., Yalcin, M., 2009. Natural durability of heartwoods from European and tropical African trees exposed to marine conditions. Afr. J. Biotechnol. 8 (18), 4425-4432.

Sivrikaya, H., Cragg, S.M., Borges, L.M.S., 2009. Variation in resistance to marine borers in commercial timbers from Turkey, as assessed by marine trial and laboratory screening. Turkish J. Agric. For. 33 (6), 569-576.

Tarkow, H., Stamm, A.J., Erickson, E.C.O., 1955. Acetylated Wood. Forest Products Laboratory Report No. 1593. Oregon State University, Madison, Wisconsin.

Westin, M., Rapp, A.O., Nilsson, T., 2006. Field test of resistance of modified wood to marine borers. Wood Mater. Sci. Eng. 1 (1), 34-38. 
Williams, J.R., Sawyer, G.S., Cragg, S.M., Simm, J., 2004. A Questionnaire Survey to Establish the Perceptions of UK Specifiers Concerning the Key Material Attributes of Timber for Use in Marine and Fresh Water Engineering. IRG/WP 04-10519. The International Research Group on Wood Preservation, Stockholm. 


\section{Table 1}

Modification agent, WPG (percentage increase in mass due to modification) and curing conditions of treatments investigated in this study; where different WPGs were adjusted by changing chemical concentration of the impregnation solution, this concentration is included in the treatment name; $\%(\mathrm{~m} / \mathrm{m})$.

\begin{tabular}{|c|c|c|c|c|}
\hline Treatment & Chemical & $\begin{array}{l}\text { Approximate mean } \\
\text { WPG }\end{array}$ & & $\begin{array}{l}\text { Curing } \\
\text { conditions }\end{array}$ \\
\hline Accoya $^{\circledR}$ & $\begin{array}{l}\text { Acetylated Radiata pine } \\
\text { Methylated melamine }\end{array}$ & $>20 \%$ & & \\
\hline MMF $10 \%$ & formaldehyde & $10 \%$ & & kiln (mild) \\
\hline MMF $25 \%$ & & $25 \%$ & & oven (dry) \\
\hline PF $25 \%$ & Phenol formaldehyde & $35 \%$ & $\begin{array}{l}\text { Field } \\
\text { trial: } \\
\text { Lab. } \\
\text { assay: }\end{array}$ & $\begin{array}{l}\text { oven (dry) } \\
\text { oven (wet) }\end{array}$ \\
\hline TEOS & Tetra-ethoxy-ortho-silane & $25 \%$ & & \\
\hline CC $0.6 \%$ & $\mathrm{CuO}(30 \%) ; \mathrm{CrO}_{3}(70 \%)$ & $3.5 \mathrm{~kg} / \mathrm{m}^{3}$ & & \\
\hline CC $2.5 \%$ & & $15 \mathrm{~kg} / \mathrm{m}^{3}$ & & \\
\hline
\end{tabular}

Table 2

Rating system for attack by teredinids according to EN 275.

\begin{tabular}{clll}
\hline Rating & Classification & Condition and appearance of test specimen on the X-ray film \\
\cline { 1 - 2 } 1 & No attack & No sign of attack \\
2 & Slight attack & Single or a few scattered tunnels covering not more than $15 \%$ of the area of the specimen \\
3 & Moderate attack & Tunnels covering not more than about $25 \%$ of the area of the test specimen \\
4 & Severe attack & Tunnels covering between $25 \%$ and $50 \%$ of the area of the specimen \\
\hline
\end{tabular}




\section{Figure legends}

Fig. 1. Average ratings of differently treated wood during five years of exposure based on the evaluation of shipworm attack of individual specimens according to EN 275.

Fig. 2. X-ray radiographs of an untreated control, and panels treated with TEOS, MMF $10 \%$ and $\mathrm{PF}(25 \%)$ (from left to right) showing the typical patterns of shipworm attack. Panels were exposed for two years.

Fig. 3. Chemical content of specimens after the first, second, and third year of exposure normalized to the median of non-exposed specimens treated in the same batch; bars: medians; error-bars: $95 \%$ confidence interval; $\mathrm{n}=10$.

Fig. 4. Faecal pellet production by Limnoria quadripunctata on differently modified wood in the (forced) feeding test; bars: medians; error bars: $95 \%$ confidence interval; $\mathrm{n}=12$.

Fig. 5. Mortality of Limnoria quadripunctata fed differently modified wood; percentage number of counting intervals in which an animal died. error bars: $95 \%$ confidence interval.

Fig. 6. Faecal pellet production, copper concentration in the water and mortality of animals fed untreated controls, treated controls or both; bars: medians; error bars: $95 \%$ confidence interval; $\mathrm{n}=20$; copper concentration: single measurement. 
Fig 1.

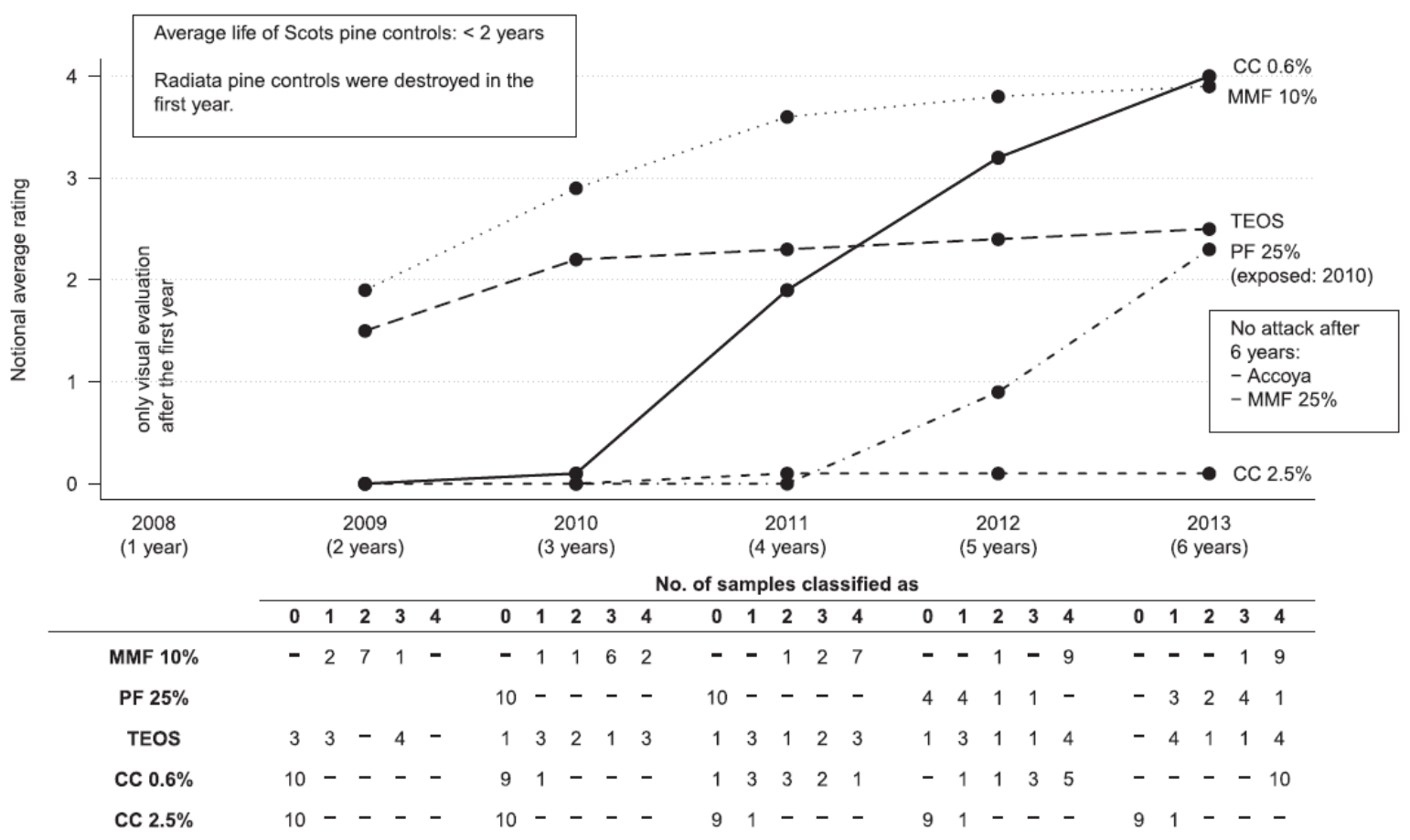

Fig 2
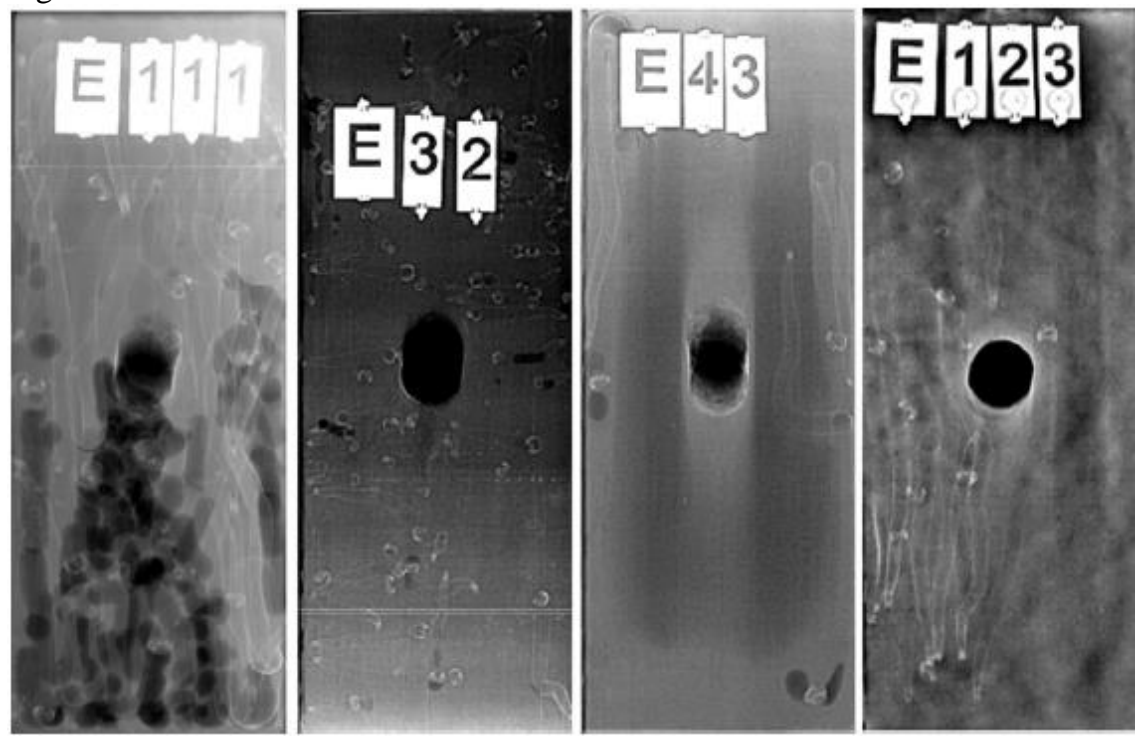


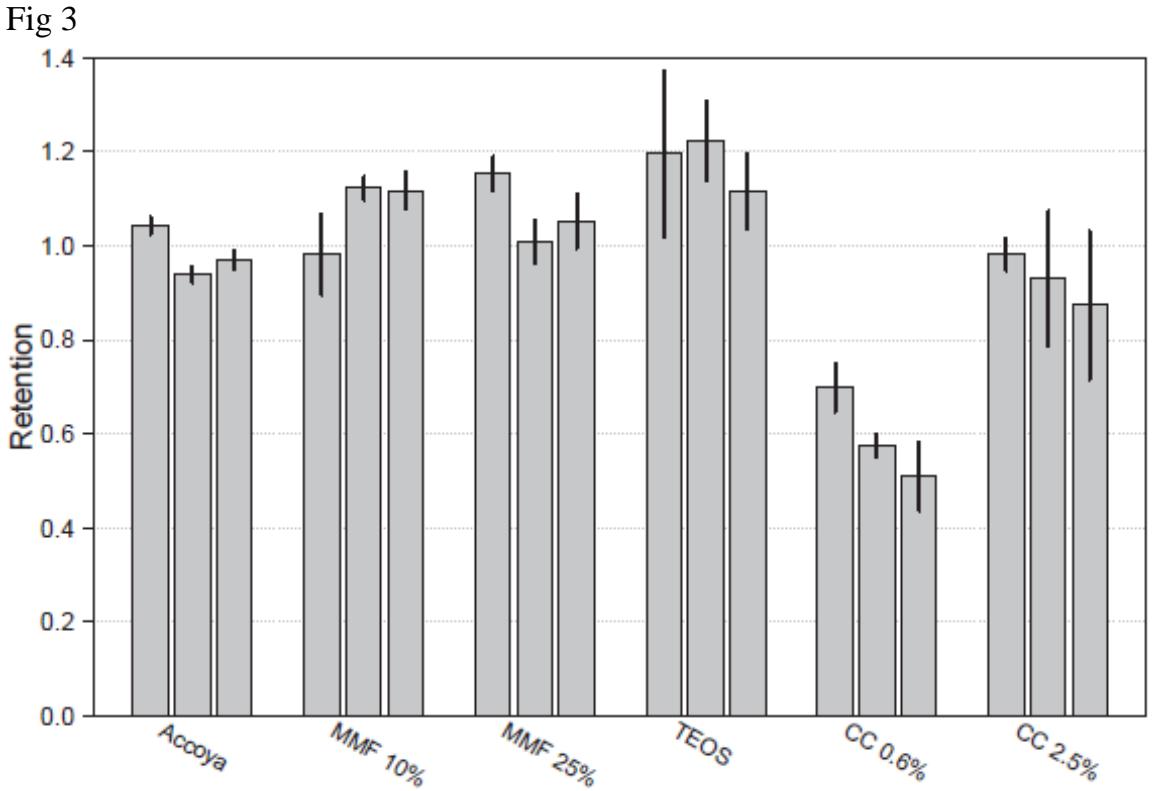

Fig 4

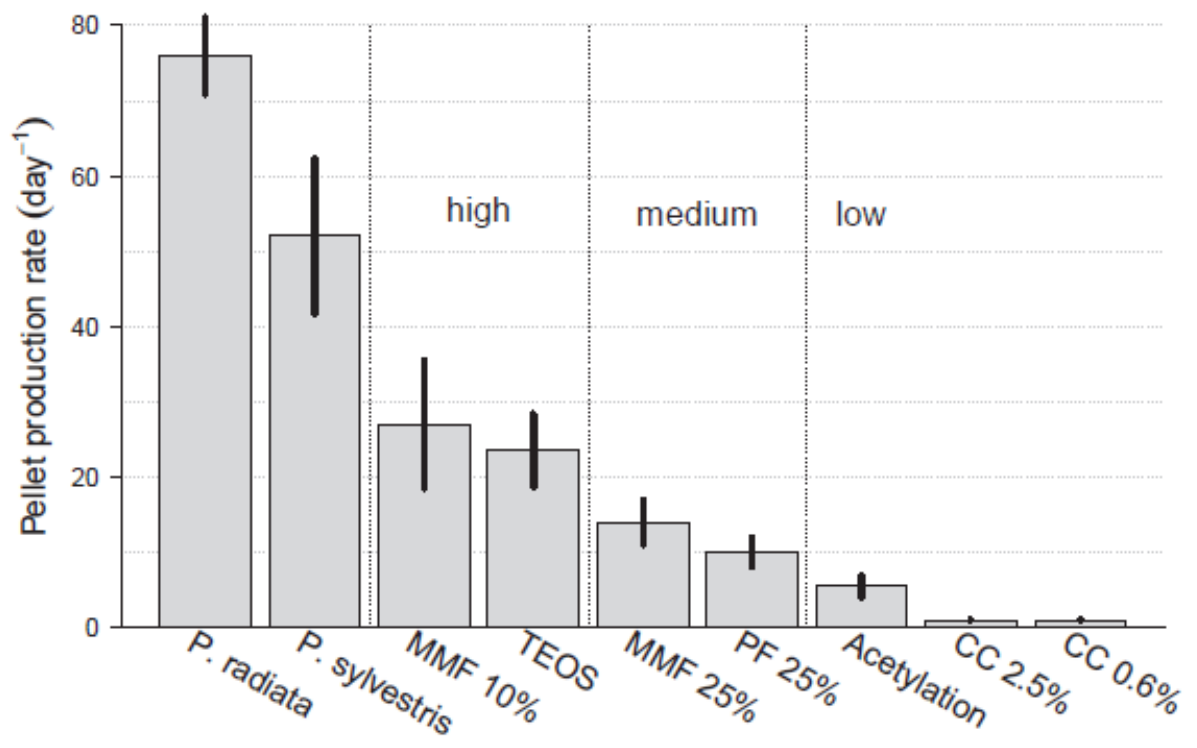


Fig 5

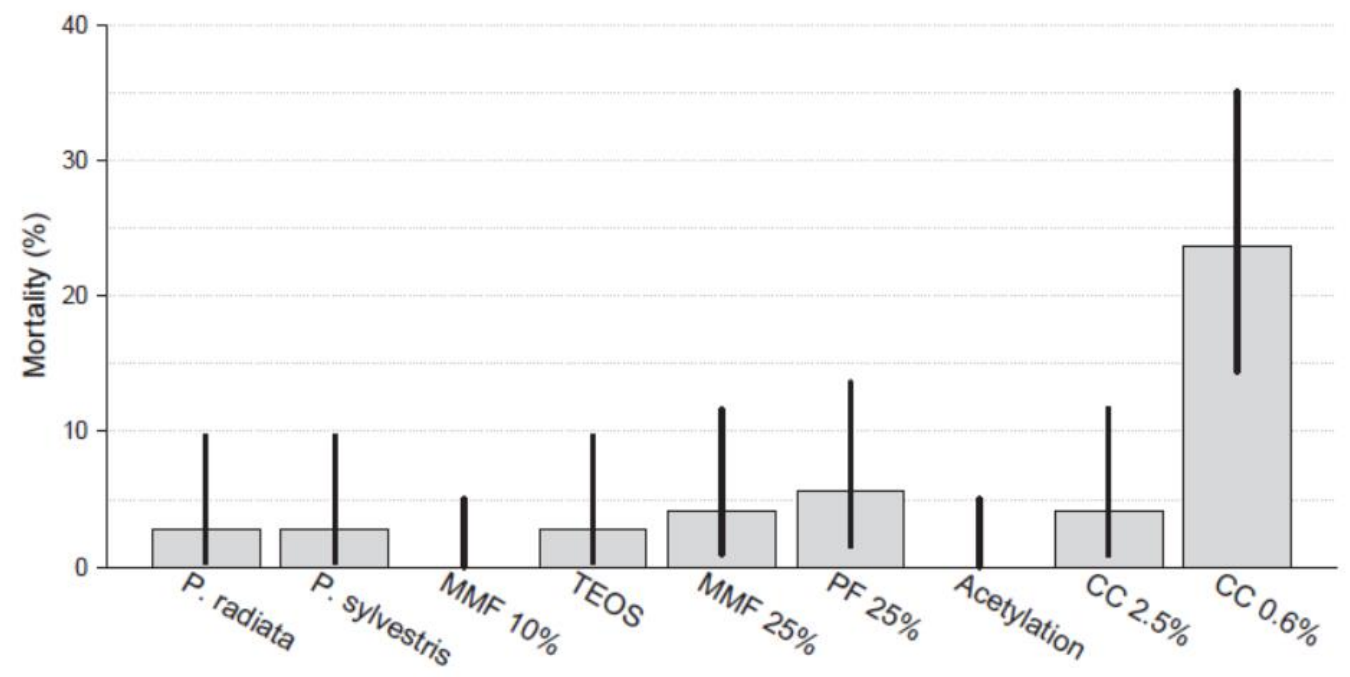

Fig 6

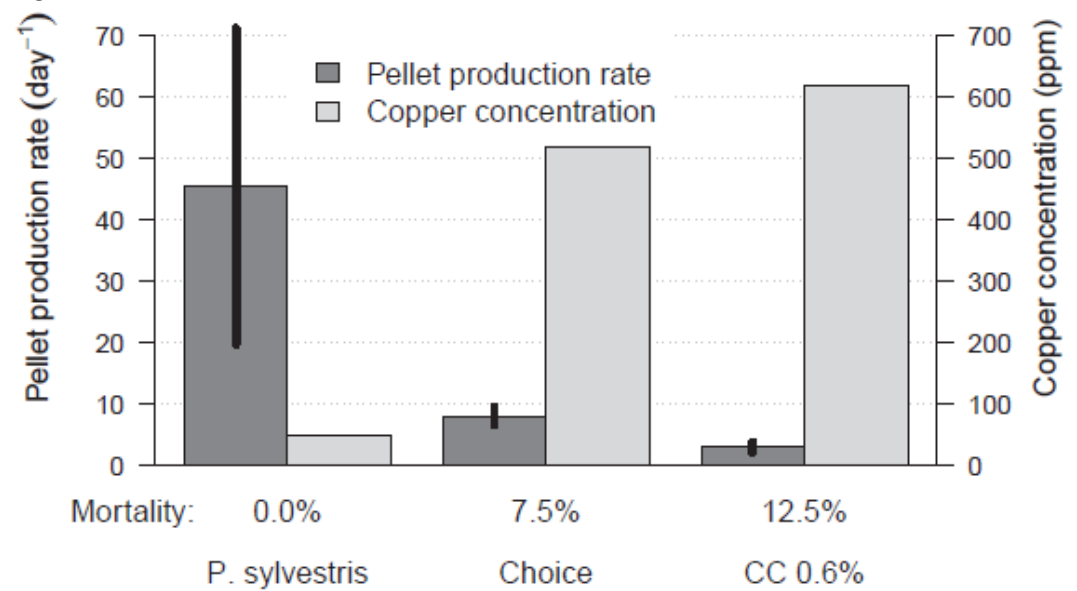

